\title{
Usher Syndrome Type 2
}

National Cancer Institute

\section{Source}

National Cancer Institute. Usher Syndrome Type 2. NCI Thesaurus. Code C126328.

A syndrome characterized by cong enital, bilateral sensorineural hearing loss that is mild to moderate in the low frequencies and severe to profound in the higher frequencies, no abnormalities in the vestibular system, and retinitis pigmentosa. 